\title{
Prioritization of the policies and practices applied in Turkey to fight against covid-19 through AHP technique
}

\section{Priorização das políticas e práticas aplicadas na Turquia para o combate ao covid-ı9 através da técnica AHP}

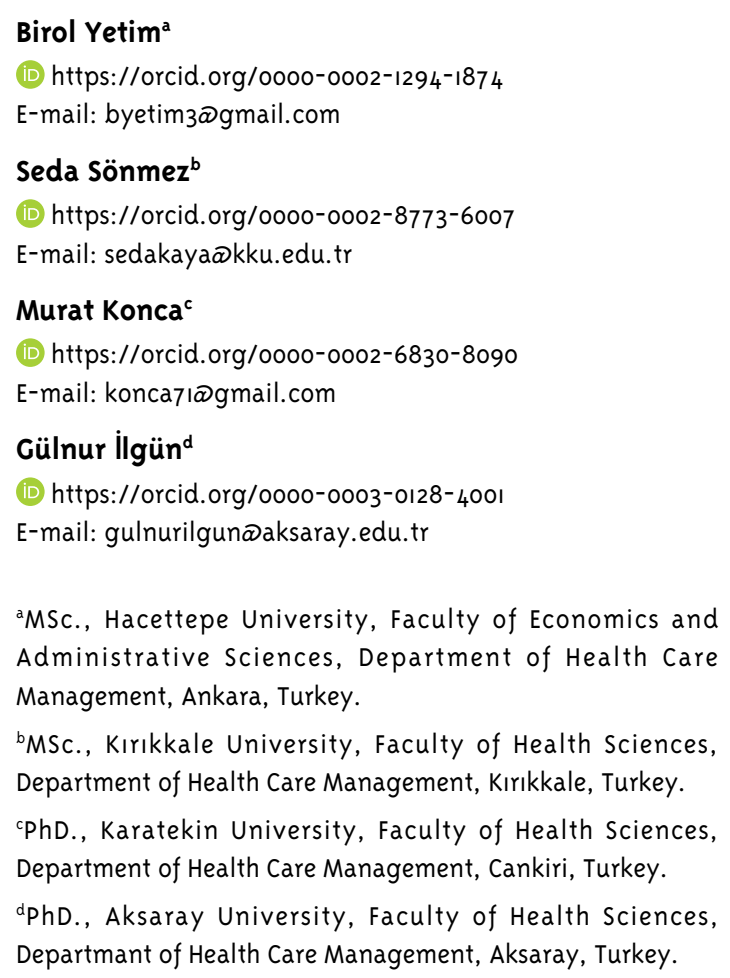
Department of Health Care Management, Kırıkkale, Turkey.

'PhD., Karatekin University, Faculty of Health Sciences, Department of Health Care Management, Cankiri, Turkey.

dPhD., Aksaray University, Faculty of Health Sciences, Departmant of Health Care Management, Aksaray, Turkey.

\section{Correspondence}

PhD. Murat Konca

Karatekin University, Faculty of Health Sciences, Department of Health Care Management, Cankiri, 18000 Turkey.

\section{Abstract}

Concerns about covid-19 become deeper globally. Due to these concerns, all countries, international health institutions, health authorities and health care professionals in the world take several measures through policies or practices to control and handle covid-19 pandemic. For example; different types of policies in the fight against covid-19 have been launched in Turkey. Therefore, in this study, we sought to determine how policies and practices against covid-19 were prioritized by health care professionals and other segments of society via AHP method. We observed that the order of importance of health care professionals and other segments of the society regarding the policies and practices used in combating the covid-19 outbreak was quite similar between the groups. The covid-19 test policy was revealed as the most important one of both groups. However, social welfare programs have more significance than economic measures for society, while health care professionals are more concerned with economic measures. With this study, we intend to provide evidence-based information to decision-makers in combating the pandemic.

Keywords: Covid-19; Policy Prioritization; AHP 


\section{Resumo}

As preocupações com a covid-19 se aprofundam globalmente. Devido a essas preocupações, todos os países, instituições internacionais de saúde, autoridades de saúde e profissionais de saúde em todo o mundo tomam várias medidas por meio de políticas ou práticas para controlar e lidar com a pandemia de covid-19. Por exemplo, diferentes tipos de políticas na luta contra a covid-19 foram lançados na Turquia. Portanto, neste estudo, o objetivo é determinar como as políticas e práticas contra a covid-19 foram priorizadas pelos profissionais de saúde e outros segmentos da sociedade por meio do método AHP. De acordo com os resultados, foi observado que a ordem de importância dos profissionais de saúde e demais segmentos da sociedade quanto às políticas e práticas utilizadas no combate ao surto de covid-19 foi bastante semelhante. A política de teste da covid-19 foi apresentada como a política mais importante de ambos os grupos, no entanto, os programas de bem-estar social têm mais importância do que as medidas econômicas para a sociedade, enquanto os profissionais de saúde se preocupam mais com as medidas econômicas. Com este estudo, pretendemos que as informações baseadas em evidências serão fornecidas para os tomadores de decisão no combate à pandemia.

Palavras-chave: Covid-19, Priorização de Políticas, AHP

\section{Introduction}

Many decisions taken in cases of emergency regarding public health may directly affect the safety, health and welfare of individuals and societies. Besides, many problems in societies, especially financial and social distresses, emerge from these decisions. The novel coronavirus (covid-19) broke out in Wuhan, China, in December 2019 and was labelled as a pandemic on March 11, 2020 by the World Health Organization (WHO). Covid-19 has influenced a lot of countries and the number of people who have come down with this disease has risen rapidly. Governments under these circumstances have been forced to take various measures to fight the pandemic.

The measures are generally restrictive, and their basic objective is to hinder spread of the disease by reducing the physical contact between individuals. This kind of actions provided positive outcomes in various outbreaks in the past as well. As an important measure, physical distance prevented person-to-person infection, so morbidity and mortality decreased (Chen et al., 2020). The above measures, which lower the physical distance between individuals, are implemented at different levels in many countries. While several countries have applied stringent measures such as curfew and prevention of domestic and international transportation, some other countries have imposed restrictions only for certain physical spaces, such as schools, workplaces and social areas, or for industries whose work involves physically close distance. Some countries have only temporarily stopped the activity of these spaces or industries (Bol et al., 2020).

Apart from hindering the spread of the disease, the other steps taken to fight against covid-19 are the treatment of infected individuals and the efforts for developing vaccines against the disease. Although it is stated that several drugs used before for different diseases may be useful to treat covid-19 (Sanders et al., 2020), scientific circles believe that this disease can be controlled only if society acquires immunity (herd immunity) to the disease when most of it (approximately 70\%) undergoes it, or when a vaccine is developed (Randolph; Barreiro, 2020). In addition to the countries which have aimed to control covid-19 
via herd immunity (e.g. Sweden), there are some countries which first adopted and then quitted this strategy (e.g. the United Kingdom). Herd immunity is a strategy debated and criticized by several circles. The ability to form herd immunity against covid-19 is based on the assumption that viral infection makes individuals acquire sufficiently protective immunity. However, the required degree to generate sterilizing immunity to covid-19 among the people is unclear in many countries (Randolph; Barreiro, 2020). This puts vaccine one step forward in fighting against covid-19. The studies for developing covid-19 vaccine are conducted at an extraordinary pace due to wordwide threatening impact of the disease. Nevertheless, vaccine development should be carried out within the frame of definite procedures, hence it seems impossible to expect the development and largescale distribution of covid-19 vaccine prior to 2021 .

There are economic dimensions of covid-19 pandemic other than the ones concerning social life and health care systems, since the pandemic has resulted in a global economic crisis as well as social restrictions, along with the distresses felt by people and loss of lives. Economic activities have slowed down or almost stopped in some countries due to social restrictions and isolation, and the speed of money circulation slowed down, based on the supply chain damage, and ultimately, unemployment has risen (Eryüzlü, 2020). The economic troubles caused by covid-19 pandemic will lead to higher costs in global economy than the global financial crisis of 2007-2008 did (Kabir et al., 2020). The governments willing to avert this problem declared economic support packages to reduce the losses caused by covid-19 pandemic. One of the estimations is that the total support packages of governments exceed 8 trillion dollar all over the world (Eryüzlü, 2020). This forecast is quite significant for showing the damage of covid-19 pandemic in global economy.

Apart from the economic dimensions of the covid-19 pandemic, there are also psychological and sociological dimensions. While the covid-19 pandemic and some steps taken within the scope of combating this pandemic cause stress and anxiety in individuals, they also create a wave of panic in societies. This panic wave has spread to almost all societies. The uncertainty about exactly when the covid-19 pandemic will disappear increases the effect of the panic wave.

Different countries take different steps to fight against covid-19. Such diversity in the procedures adopted to struggle with the disease results from the differences in social structure, economic and financial capacity and sources between countries. Turkey takes various steps for fighting against covid-19. Even though the first case in Turkey has been seen on March 11, 2020, Turkey has taken the measures against this disease on early days of 2020 (İşlek et al., 2020). The covid-19 measures of Turkey can be grouped under two main titles: the measures taken as part of health and other part of industries. In health industry, a scientific advisory board has been initially established, and then the treatment protocol has been determined and the studies on the development of drugs and vaccine have started. The measures taken in other industries to reduce spread and economic burden of the disease contain suspension of education, mask requirement, quarantine, travel restriction, partial curfew, practices of flexible working model and economic precautions (İşlek et al., 2020). Despite these measures since the start of the pandemic, a total of 52,00o people in Turkey have lost their lives due to covid-19. In a total of 70 million tests conducted in Turkey, 5.9 million people were tested positive. The total number of people recovering is 5.5 million (Turkey, 2021).

In Turkey, various economic and fiscal measures have been taken to cover the economic losses of individuals. Several economic packages come together with the monetary expansion actions of the Central Bank. As part of these economic packages, export and import prohibitions and restrictions have been imposed on certain products, some of the goods and service groups have been subject to price cap practices, income support has been provided to the workers who took unpaid leave, various loan supports have been given and production incentives have been maintained (Eryüzlü, 2020).

Some measures taken by the government to fight covid-19 are discussed in Turkey. From such perspective, this study seeks to determine how the policies and practices adopted by Turkey 
to fight covid-19 are prioritized by health care professionals and society.

\section{Method}

In line with the aim of the study, literature was reviewed and the research model was set by identifying the policies and practices implemented against the pandemic. The relevant policies and practices are as follows: (1) covid-19 test policy, (2) contact monitoring policy, (3) shutdown of the public areas and facilities, (4) travel restriction, (5) mask requirement in public places, (6) social welfare programs and (7) economic measures. To achieve the purpose of this study, the Analytic Hierarchy Process (AHP) was used, which is one of the multi-criteria decision-making methods. However, a two-level AHP model was formed depending on the aim of this study, which is the prioritization of alternatives (Figure 1). Therefore, the first and second levels of the model include problem of the research and the alternatives about the relevant policies and practices, respectively.

Figure I- Policies and practices considered within the scope of the study

\begin{tabular}{|c|c|}
\hline \multirow{12}{*}{ 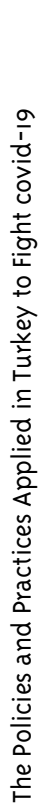 } & Al: Covid-19 Test Policy \\
\hline & \multirow{2}{*}{$\begin{array}{l}\text { A2: Contact Monitoring } \\
\text { Policy }\end{array}$} \\
\hline & \\
\hline & \multirow{2}{*}{$\begin{array}{l}\text { A3: Shutdown of the Public } \\
\text { Areas and Facilities }\end{array}$} \\
\hline & \\
\hline & \multirow{2}{*}{ A4: Travel Restriction } \\
\hline & \\
\hline & \multirow{2}{*}{$\begin{array}{l}\text { A5: Mask Requirement in } \\
\text { Public Places }\end{array}$} \\
\hline & \\
\hline & \multirow{2}{*}{$\begin{array}{l}\text { A6: Social Welfare } \\
\text { Programs }\end{array}$} \\
\hline & \\
\hline & A7: Economic Measures \\
\hline & \\
\hline
\end{tabular}

A: Alternatives
AHP is one of the multi-criteria decisionmaking techniques that was first developed in the 1970's by Thomas Saaty (Ishizaka; Labib, 2011). It is used with the purpose of finding solution for the problems regarding decisiontaking and estimation-making in multivariate environments in which especially multiple criteria and alternatives exist and evaluations are usually subjective (Emrouznejad; Marra, 2017). The procedure generates weights of priorities for alternatives by hierarchically regulating the objective, criteria and sub-criteria (Bernasconi et al., 2010). It can be said that AHP consists of qualitative and quantitative approaches due to separating problems into a hierarchy of elements at different levels and determining their significance levels through pairwise comparisons, respectively (Wong; Li, 2008).

AHP technique is frequently used in health industry, in which uncertainty is high, with the aim of diagnosing, making patient attend the treatment, assessing the treatment options, choosing health technologies, planning human resources and evaluating health policies (Liberatore; Nydick, 2008). Several researches that include group studies (e.g. health care professionals and patients) as well a specific sample group (e.g. only patients) which comprises health care professionals, managers, patients and other parties were conducted in practice (Hummel; IJzerman, 2011).

AHP technique is made up of six stages (Atanasova-Pacemska et al., 2015; Cabala, 2010; Cheng; Li, 2001; Saaty, 1987, 1990, 2008):

1) Stage 1 - Definition of the problem and determination of the selection criteria and alternatives: The first stage of the AHP technique contains definition of the problem and determination of the criteria (sub-criteria if any) and alternatives on the related problem. Thus, the purpose of the problem is at the first level of AHP hierarchy while the second level comprises the criteria and their sub-criteria, if any. The alternatives to be used to solve the problem form the last level of hierarchy. Literature review and expert opinions are utilized to determine the related criteria and alternatives. 
2) Stage 2-Generation of pairwise comparison matrices: The elements at every level of the decision hierarchy are ranked via pairwise comparisons. Saaty's Pairwise Comparison Scale (Table 1) is used to identify the significance level between two elements.

\begin{tabular}{|c|c|}
\hline Importance Level & Definition \\
\hline । & Equally important \\
\hline 3 & Moderately important \\
\hline 5 & Important or strongly important \\
\hline 7 & Very strongly important \\
\hline 9 & Extremely important \\
\hline $2,4,6,8$ & Intermediate values \\
\hline
\end{tabular}

A pairwise comparison matrix is formed as follows after comparing all elements dyadically.

$$
A=\left[\begin{array}{cccc}
a_{11} & a_{12} & \ldots & a_{1 n} \\
a_{21} & a_{22} & \ldots & a_{2 n} \\
\cdot & & & \cdot \\
\cdot & & & \cdot \\
\cdot & & & \cdot \\
a_{n 1} & a_{n 2} & \ldots & a_{n n}
\end{array}\right]
$$

Pairwise comparison matrix is mainly a square matrix with $n * n$ dimension. The value corresponds to 1 when the elements on diagonal of the matrix are $(i=j)$. In other words, an element is compared with itself, so it has equal significance. Comparisons are made for the values on the diagonal. The following formula is used for the values below the diagonal.

$$
a_{j i}=\frac{1}{a_{i j}}
$$

3) Stage 3-Normalization of pairwise comparison matrices: At this stage, the pairwise comparison matrix obtained at the former step is normalized. In consequence of the normalization, matrix $\mathrm{A}$ is converted into matrix $\mathrm{B}=[b i j]$. Elements of matrix $\mathrm{B}$ are calculated based on the following formula.

$$
b_{i j}=\frac{a_{i j}}{\sum_{i=1}^{n} a_{i j}}
$$

4) Stage 4 - Determination of the weights of criteria and/or alternatives: Arithmetic mean of the row elements in normalization matrices obtained from the pairwise comparison matrices is calculated and the percentage values of weight (W) are determined in line with the following formula at this stage.

$$
w_{i}=\frac{\sum_{j=1}^{n} b_{i j}}{n}
$$

5) Stage 5 - Testing of the consistency: At this stage of the technique, consistency of weights should be tested. In case of consistency, decisionmakers pass a consistent judgment on pairwise comparisons. It is unlikely for all comparison matrices to be consistent, so a reasonable inconsistency is expected to a certain extent. This limit is 0.05 and 0.08 for matrices $3 * 3$ and $4 * 4$, respectively. The limit is 0.10 for greater matrices. The weights concerning the consistency ratios below this limit are deemed valid. To calculate consistency, normalization matrix should be first multiplied with the weight values and priority vectors should be calculated. Afterwards, the maximum $\lambda$ value is found with the following formula by dividing total value of the priority vector into number of factors

$$
\lambda=\frac{\sum_{i=1}^{n} E_{i}}{n}
$$

The below formula is used to calculate the consistency index (CI).

$$
C I=\frac{\lambda-n}{n-1}
$$

Lastly, CR is obtained by dividing CI into random index (RI) which refers to the number of factors in Table 2.

$$
C R=\frac{C I}{R I} \quad \text { (7) }
$$


Table 2- Random indicators

\begin{tabular}{|l|c|c|c|c|c|c|c|c|c|c|}
\hline Number of factors & 1 & 2 & 3 & 4 & 5 & 6 & 7 & 8 & 9 & 10 \\
\hline RI & 0.00 & 0.00 & 0.58 & 0.90 & 1.12 & 1.24 & 1.32 & 1.41 & 1.45 & 1.49 \\
\hline
\end{tabular}

6) Stage 6 - Determination of the priorities for alternatives: Alternatives are listed based on the attained weights at the last stage after it is seen that the consistency values of weights are below the required level. The alternative with the highest weight becomes first as the alternative with the lowest weight is the last one.

A survey form that consists of pairwise comparisons of the alternatives was generated to reach the purpose of the research. The survey form prepared was sent to the health care professionals and citizens who reside in Ankara province, via sampling method between July 01, 2020 and July 15 , 2020. The survey form was applied electronically and 69 surveys were obtained. These surveys were reviewed and the surveys with unanswered questions were excluded. As a result, analyses were performed with 43 surveys. Even though there is not a definite rule about the number of samples in AHP studies, the general view is that very broad sample sizes are not required for these studies. It should be noted that the results received due to the dependence of such studies on subjective judgments are not absolute representation of the universe (Schmidt et al., 2015). The data obtained from surveys were analyzed separately with respect to both health care professionals and society. Microsoft Excel program was used to conduct the analyses.

\section{Results}

As mentioned in method section, AHP is an application basically made up of six steps. The first step is determination of the selection criteria and alternatives. Nevertheless, the main purpose of this study is to reveal the significance level of the policies and practices which are extensively used in Turkey to fight covid-19 pandemic, hence only alternative policies and practices were considered (Figure 1).

The following step of the AHP technique is generation of pairwise comparison matrix. The survey form prepared to generate the relevant matrix was implemented in different samples: health care professionals and others. Individual and demographical features of the study's participants are as follows (Table 3).

Table 3 - Individual and demographical features of the participants in the study

\begin{tabular}{|c|c|c|}
\hline Variables & Frequency & Percentage \\
\hline \multicolumn{3}{|l|}{ Gender } \\
\hline Male & 21 & 48.84 \\
\hline Female & 22 & 51.16 \\
\hline Total & 43 & 100.00 \\
\hline \multicolumn{3}{|l|}{ Age } \\
\hline $20-24$ & 16 & 37.21 \\
\hline $25-29$ & 15 & 34.88 \\
\hline $30-34$ & 9 & 20.93 \\
\hline 35 and above & 3 & 6.98 \\
\hline Total & 43 & 100.00 \\
\hline \multicolumn{3}{|l|}{ Occupation } \\
\hline \multicolumn{3}{|l|}{ Healthcare } \\
\hline professionals & 17 & 39.53 \\
\hline Other & 26 & 60.47 \\
\hline Total & 43 & 100.00 \\
\hline \multicolumn{3}{|l|}{ Monthly Income } \\
\hline $3200 €$ and below & 13 & 30.23 \\
\hline $3201-5000 も$ & 17 & 39.53 \\
\hline 5001 Ł and above & 13 & 30.23 \\
\hline Total & 43 & 100.00 \\
\hline \multicolumn{3}{|c|}{$\begin{array}{l}\text { Have you or any member of your family been diagnosed } \\
\text { with covid-19? }\end{array}$} \\
\hline Yes & 6 & 13.95 \\
\hline No & 37 & 86.05 \\
\hline Total & 43 & 100.00 \\
\hline
\end{tabular}

According to Table 3, 51.16\% and $48.84 \%$ of the participants in the study are female and male, respectively. Almost $70 \%$ of the participants are under the age of 30 whereas $\mathbf{2 7 . 9 1 \%}$ are 30 years and older. Regarding occupation, $39.53 \%$ are health care professionals. In the study, 30.23\% 
of the participants have a monthly income of $3200 €$ and below, while $39.53 \%$ of them earn from 3201 to 5000 . The individuals who have a monthly income of $5000 €$ and above make up approximately one-third of all participants (30.23\%). Besides, covid-19 diagnosis was made for the families of $13.95 \%$ of the participants (themselves or family member(s)).

The survey forms applied to the participants were assessed in two different groups, considering their occupations. Thus, two separate comparison matrices were prepared. The comparison matrices obtained from health care professionals (Table 4a) and society (Table $4 \mathrm{~b}$ ) are given below.
At the next step of AHP, all elements of pairwise comparison matrices are normalized by dividing the values in each decision matrices generated in Tables $4 \mathrm{a}$ and $4 \mathrm{~b}$ into the sum of the columns. Normalized matrices attained from normalization process are shown in Table $5 \mathrm{a}$ and Table $5 \mathrm{~b}$.

The row means of the normalization matrices generated from the pairwise comparison matrices are calculated and percentage values of weight (w) concerning the criteria are determined at the fourth step of the AHP technique. The weight values obtained from the study are calculated separately as health care professionals and society. They can be found in Table 6 .

Table 4a - Pairwise comparison matrix, health care professionals

\begin{tabular}{|c|c|c|c|c|c|c|c|}
\hline A & $\mathrm{Al}$ & $\mathrm{A} 2$ & $\mathrm{~A}_{3}$ & $\mathrm{~A}_{4}$ & A5 & A6 & A7 \\
\hline $\mathrm{Al}$ & 1.0000 & 3.8864 & 1.6617 & 2.1906 & 1.2783 & 3.6431 & 2.9983 \\
\hline $\mathrm{A}_{2}$ & 0.2573 & 1.0000 & 2.4733 & 3.3521 & 1.9582 & 4.2623 & 2.3060 \\
\hline $\mathrm{A}_{3}$ & 0.6018 & 0.4043 & 1.0000 & 3.4811 & 3.1285 & 3.5266 & 3.3025 \\
\hline $\mathrm{A}_{4}$ & 0.4565 & 0.2983 & 0.2873 & 1.0000 & 1.1484 & 1.8321 & 1.4504 \\
\hline A5 & 0.7823 & 0.5107 & 0.3196 & 0.8708 & 1.0000 & 5.9479 & 4.2176 \\
\hline A6 & 0.2745 & 0.2346 & 0.2836 & 0.5458 & 0.1681 & 1.0000 & 0.8079 \\
\hline A7 & 0.3335 & 0.4336 & 0.3028 & 0.6895 & 0.2371 & 1.2378 & 1.0000 \\
\hline
\end{tabular}

Table $4 b-$ Pairwise comparison matrix, society

\begin{tabular}{ccccccccc} 
A & Al & A2 & A3 & A4 & A5 & A6 & A7 \\
\hline Al & 1.0000 & 3.2684 & 2.4770 & 3.1193 & 1.2922 & 2.3714 & 2.8874 \\
\hline A2 & 0.3060 & 1.0000 & 2.4539 & 2.7810 & 1.4372 & 3.1725 & 2.5703 \\
\hline A3 & 0.4037 & 0.4075 & 1.0000 & 3.9234 & 1.7823 & 3.1588 & 2.3795 \\
\hline A4 & 0.3206 & 0.3596 & 0.2549 & 1.0000 & 1.9633 & 3.1634 & 1.6315 \\
\hline A5 & 0.7739 & 0.6958 & 0.5611 & 0.5094 & 1.0000 & 3.3341 & 2.6461 \\
\hline A6 & 0.4217 & 0.3152 & 0.3166 & 0.3161 & 0.2999 & 1.0000 & 1.3334 \\
\hline A7 & 0.3463 & 0.3891 & 0.4202 & 0.6129 & 0.3779 & 0.7500 & 1.0000 \\
\hline
\end{tabular}

Table 5a - Normalization matrix, health care professionals

\begin{tabular}{ccccccccc} 
A & Al & A2 & A3 & A4 & A5 & & A6 & A7 \\
\hline Al & 0.2698 & 0.5742 & 0.2626 & 0.1806 & 0.1433 & 0.1698 & 0.1864 \\
\hline A2 & 0.0694 & 0.1478 & 0.3908 & 0.2764 & 0.2196 & 0.1987 & 0.1434 \\
\hline
\end{tabular}


Table 5a-Continuation

\begin{tabular}{ccccccccc} 
A & Al & A2 & A3 & A4 & A5 & A6 & A7 \\
\hline A3 & 0.1624 & 0.0597 & 0.1580 & 0.2870 & 0.3508 & 0.1644 & 0.2053 \\
\hline A4 & 0.1232 & 0.0441 & 0.0454 & 0.0824 & 0.1288 & 0.0854 & 0.0902 \\
\hline A5 & 0.2111 & 0.0755 & 0.0505 & 0.0718 & 0.1121 & 0.2773 & 0.2622 \\
\hline A6 & 0.0741 & 0.0347 & 0.0448 & 0.0450 & 0.0189 & 0.0466 & 0.0502 \\
\hline A7 & 0.0900 & 0.0641 & 0.0478 & 0.0568 & 0.0266 & 0.0577 & 0.0622 \\
\hline
\end{tabular}

Table $5 b-$ Normalization matrix, society

\begin{tabular}{ccccccccc} 
A & Al & A2 & A3 & A4 & A5 & A6 & A7 \\
\hline A1 & 0.2799 & 0.5079 & 0.3310 & 0.2544 & 0.1585 & 0.1399 & 0.1998 \\
\hline A2 & 0.0857 & 0.1554 & 0.3279 & 0.2268 & 0.1763 & 0.1872 & 0.1779 \\
\hline A3 & 0.1130 & 0.0633 & 0.1336 & 0.3200 & 0.2186 & 0.1864 & 0.1647 \\
\hline A4 & 0.0897 & 0.0559 & 0.0341 & 0.0816 & 0.2408 & 0.1866 & 0.1129 \\
\hline A5 & 0.2166 & 0.1081 & 0.0750 & 0.0415 & 0.1227 & 0.1967 & 0.1831 \\
\hline A6 & 0.1180 & 0.0490 & 0.0423 & 0.0258 & 0.0368 & 0.0590 & 0.0923 \\
\hline A7 & 0.0970 & 0.0605 & 0.0562 & 0.0500 & 0.0464 & 0.0442 & 0.0692 \\
\hline
\end{tabular}

Table 6 - Percentage weights and priority order of the alternatives

\begin{tabular}{|c|c|c|c|c|}
\hline Alternatives & $w_{1}$ (Healthcare Professionals) & Ranking & $w_{2}$ (Society) & Ranking \\
\hline $\mathrm{Al}$ & 0.25537 & $\mathbf{I}$ & 0.26735 & $\mathbf{I}$ \\
\hline $\mathrm{A} 2$ & 0.20668 & 2 & 0.19101 & 2 \\
\hline $\mathrm{A}_{3}$ & 0.19824 & 3 & 0.17147 & 3 \\
\hline $\mathrm{A}_{4}$ & 0.08564 & 5 & 0.11451 & 5 \\
\hline A5 & 0.15150 & 4 & 0.13482 & 4 \\
\hline A6 & 0.04499 & 7 & 0.06055 & 6 \\
\hline A7 & 0.05799 & 6 & 0.06058 & 7 \\
\hline
\end{tabular}

At the following step of AHP, consistency of the weights attained at the fourth step of the technique should be tested. Results of the consistency tests are given in Table 7 .

As Table 7 shows, CR values of both models are lower than o.10. For this reason, the weights found at the fourth step are consistent (Table 6). According to this outcome, covid-19 test policy reveals as the most important policy of both groups. The said policy is followed by contact monitoring policy, shutdown of the public areas and facilities, mask requirement and travel restriction, respectively. However, social welfare programs have more significance than economic measures for society while health care professionals care about economic measures more. 
Table 7-Calculation of the consistency of weights

\begin{tabular}{lll} 
Criteria & $\begin{array}{l}\mathrm{w}_{1} \text { (Healthcare } \\
\text { Professionals) }\end{array}$ & $\mathrm{w}_{2}$ (Society) \\
$\lambda_{\text {maks }}$ & 7.77265432 & 7.753642591 \\
$\mathrm{Cl}$ & 0.12877572 & 0.125607098 \\
$\mathrm{CR}$ & 0.097557364 & 0.095156893 \\
\hline
\end{tabular}

\section{Final considerations}

The recent covid-19 virus is the seventh member of coronavirus family which can infect humans (Acter et al., 2020; Dawood, 2020; Li et al., 2020; Zhu et al., 2020a; Zhu et al., 2020b). It was asserted that genetic code of covid-19 virus resembles the other family members, SARS and MERS at a ratio of $82 \%$ and $50 \%$, respectively (Zhang et al., 2020). SARS, MERS and covid-19 viruses are known to cause severe respiratory distress (Dawood, 2020; Petrosillo et al., 2020; Zhang et al., 2020; Zhu et al., 202ob). Nevertheless, concerns for covid-19 become deeper globally because of the following reasons: virus is brand new; it has been increasing rapidly all around the world; there is still limited information about epidemiology, pathogenesis and clinical features of the virus and any proven anti-viral treatment or vaccine for this virus has not been found, yet (Acter et al., 2020; Hamid et al., 2020; Rothan; Byrareddy, 2020; Souza et al., 2020). Due to these concerns, all countries, international health institutions, health authorities and health care professionals in the world take several measures through policies or practices to control and handle covid-19 pandemic. In this scope, Turkey defined numerous policies and practices against the pandemic as well. In line with the above point, this study sought to determine the significance level of the policies and practices which are used broadly to fight covid-19 pandemic, from the perspectives of both health care professionals and society.

From the perspective of health care professionals, significance of the policies and practices used to struggle with the pandemic are listed in descending order within the analysis as follows; (1) covid-19 test policy, (2) contact monitoring policy, (3) shutdown of the public areas and facilities, (4) mask requirement in public places, (5) travel restriction, (6) economic measures and (7) social welfare programs. On the other hand, the rank of the policies and practices from the perspective of society were found as follows; (1) covid-19 test policy, (2) contact monitoring policy, (3) shutdown of the public areas and facilities, (4) mask requirement in public places, (5) travel restriction, (6) social welfare programs and (7) economic measures. All in all, it is seen that priority orders of health care professionals and society regarding the policies and practices used against covid-19 pandemic are quite similar. We consider that such similar points of view of health care professionals and society result from the similar knowledge and awareness levels of both groups depending on the abundance of information about covid-19 pandemic in media. According to research findings, the only difference between health care professionals and society is seen in the order of social welfare programs and economic measures. In other words, social welfare programs have more significance than economic measures for society while health care professionals care about economic measures more than social welfare programs. This distinction between the two groups originates from the fact that already employed health care professionals are out of the scope of social welfare programs.

We discovered that the most substantial practice for both health care professionals and society as part of the struggle with covid-19 is "covid-19 test policy." Thus, it can be suggested that more resources can be transferred to raise the number of tests. But, in Turkey, covid-19 tests are applied only to the people found in close contact with covid-19 individuals and / or showing significant symptoms such as cough, headache, taste, loss of smell. This situation poses a problem in identifying individuals who are infected in the general population but do not show symptoms. For this reason, the covid-19 test policy should be reviewed and changed to address a much larger part of the society.

In consequence, the concerns for covid-19 that has broken out in China in December 2019 and spread around the world in a very short time have been rising. The single cause of this increase is related not only to the burden of this pandemic on community 
health care, but also to its damage on global and local economies. Hence, taking influential and quick measures within the fight against the pandemic is of capital importance for both national economy and community health care. From this point of view, the results of this study will be a guide for policy-makers in this continuum. Moreover, it is envisaged that these results will provide significant information to decision-makers regarding transfer of resources to be used in fighting the pandemic.

This survey is the first study that seeks to prioritize the policies and practices which are applied to fight covid-19 in Turkey, from the perspectives of both health care professionals and society. We suggest, for the future studies, the prioritization of alternatives in the presence of numerous criteria. In addition, we recommend new studies considering the economic, psychological and sociological effects of the pandemic.

\section{References}

ACTER, T. et al. Evolution of severe acute respiratory syndrome coronavirus 2 (SARSCoV-2) as coronavirus disease 2019 (COVID-19) pandemic: A global health emergency. Science of the Total Environment, Amsterdam, v. 730, 2020. DOI: 10.1016/j.scitotenv.2020.138996

ATANASOVA-PACEMSKA, T.; LAPEVSKI, M.; TIMOVSKI, R. Analytical Hierarchical Process (AHP) method application in the process of selection and evaluation. In: INTERNATIONAL SCIENTIFIC CONFERENCE, 2014, Gabrovo. Anais...Gabrovo: Unitech, 2014.

BERNASCONI, M.; CHOIRAT, C.; SERI, R. The analytic hierarchy process and the theory of measurement. Management science, Baltimore, v. 56, n. 4, p. 699-711, 2010. DOI: 10.2307/27784145 BOL, D. et al. The effect of COVID-19 lockdowns on political support: Some good news for democracy? European Journal of Political Research, Hoboken, v. 6o, n. 4, 2020. DOI: 10.1111/1475-6765.12401

CABAŁA, P. Using the analytic hierarchy process in evaluating decision alternatives. Operations research and decisions, Wrocław, v. 1, p. 5-23, 2010.
CHEN, S. et al. COVID-19 control in China during mass population movements at New Year. The Lancet, London, v. 395, n. 10226, p. 764-766, 2020. DOI: 10.1016/So140-6736(20)30421-9

CHENG, E. W. L.; LI, H. Analytic hierarchy process. Measuring Business Excellence, Bingley, v. 5, n. 3, 2001. DOI: 10.1108/EUMooooooooo5864

DAWOOD, A. A. Mutated COVID-19, may foretells mankind in a great risk in the future. New Microbes and New Infections, Amsterdam, v. 35, 2020. DOI: 10.1016/j.nmni.2020.100673

DE SOUZA, W. M. et al. Epidemiological and clinical characteristics of the early phase of the COVID-19 epidemic in Brazil. Nature Human Behaviour, New York, v. 4, 2020. DOI: 10.1038/ S41562-020-0928-4

EMROUZNEJAD, A.; MARRA, M. The state of the art development of AHP (1979-2017): a literature review with a social network analysis. International Journal of Production Research, Abingdon, v. 55, n. 22, p. 6653-6675, 2017.

ERYÜZLÜ, H. Covid-19 Ekonomik Etkileri ve Tedbirler: Türkiye'de "Helikopter Para” Uygulamasi. Ekonomi Maliye İșletme Dergisi, Turkey, v. 3, n. 1, p. 10-19. DOI: 10.46737/emid.745621

HAMID, S.; MIR, M. Y.; ROHELA, G. K. Noval coronavirus disease (COVID-19): A pandemic (epidemiology, pathogenesis and potential therapeutics). New Microbes and New Infections, Amsterdam, v. 35, 2020.

HUMMEL, M.; IJZERMAN, M. The past and future of the AHP in health care decision making. In: INTERNATIONAL SYMPOSIUM ON THE ANALYTIC HIERARCHY PROCESS, 11, 2011, Sorrento. Proceedings... Sorrento: ISAHP, 2011. ISHIZAKA, A.; LABIB, A. Review of the main developments in the analytic hierarchy process. Expert systems with applications, Amsterdam, v. 38, n. 11, p. 14336-14345, 2011. DOI: 10.1016/j. eswa.2011.04.143

İŞLEK, E. et al. COVID-19 Pandemi Yönetiminde Türkiye Örneği: Sağlık Politikası Uygulamaları ve Stratejileri. Ankara: Tüspe Publishing, 2020. 
KABIR, M. et al. COVID-19 economic cost; impact on forcibly displaced people. Travel Medicine and Infectious Disease, Amsterdam, v. 35, n. 101661, 2020. DOI: 10.1016/j.tmaid.2020.101661

LI, H. et al. Coronavirus disease 2019 (COVID-19): current status and future perspective. International journal of antimicrobial agents, Amsterdam, v. 55, n. 5, 2020. DOI: 10.1016/j.ijantimicag.2020.105951

LIBERATORE, M. J.; NYDICK, R. L. The analytic hierarchy process in medical and health care decision making: A literature review. European Journal of Operational Research, Amsterdam, v. 189, n. 1, p. 194-207, 2008. DOI: 10.1016/j. ejor.2007.05.001

PETROSILLO, N. et al. COVID-19, SARS and MERS: are they closely related? Clinical Microbiology and Infection, Amsterdam, v. 26, n. 6, 2020. DOI: 10.1016/j.cmi.2020.03.026

RANDOLPH, H. E.; BARREIRO, L. B. Herd Immunity: Understanding COVID-19. Immunity, Amsterdam, v. 52, n. 5, p. 737-741, 2020. DOI: 10.1016/j.immuni.2020.04.012

ROTHAN, H. A.; BYRAREDDY, S. N. The epidemiology and pathogenesis of coronavirus disease (COVID-19) outbreak. Journal of autoimmunity, Amsterdam, v. 109, n. 102433, 2020. DOI: https://doi.org/10.1016/j.jaut.2020.102433

SAATY, R. W. The analytic hierarchy process: what it is and how it is used. Mathematical modelling, Amsterdam, v. 9, n. 3/5, p. 161-176,1987. DOI: 10.1016/0270-0255(87)90473-8

SAATY, T. L. Decision making with the analytic hierarchy process. International journal of services sciences, Bingley, v. 1, n. 1, p. 83-98, 2008. DOI: 10.1504/IJSSCI.2008.017590

SAATY, T. L. How to make a decision: the analytic hierarchy process. European journal of operational research, Amsterdam, v. 48, n. 1, p. 9-26, 1990. DOI: 10.1016/0377-2217(90)90057-I

SANDERS, J. M. et al. Pharmacologic treatments for coronavirus disease 2019 (COVID-19): a review. Jama, Chicago, v. 323, n. 18, p. 1824-1836, 2020. DOI: 10.1001/jama.2020.6019
SCHMIDT, K. et al. Applying the Analytic Hierarchy Process in healthcare research: A systematic literature review and evaluation of reporting. $B M C$ medical informatics and decision making, London, v. 15, n. 112, 2015. DOI: 10.1186/s12911-015-0234-7

TURKEY. Ministry of Health. COVID-19 Information platform. Ankara, 2021. Disponível em: https://covid19.saglik.gov.tr/TR-66935/genelkoronavirus-tablosu.html Acesso em: 05 Aug 2021.

WONG, J. K. W.; LI, H. Application of the analytic hierarchy process (AHP) in multi-criteria analysis of the selection of intelligent building systems. Building and Environment, Amsterdam, v. 43, n. 1, p. 108-125, 2008. DOI: 10.1016/j. buildenv.2006.11.019

ZHANG, C.; SHI, L.; WANG, F. S. Liver injury in COVID-19: management and challenges. The Lancet Gastroenterology \& Hepatology, London, v. 5, n. 5 , p. 428-430, 2020. DOI: 10.1016/S2468-1253(20)30057-1

ZHU, N. et al. A novel coronavirus from patients with pneumonia in China, 2019. New England Journal of Medicine, Boston, v. 382, 2020. DOI: 10.1056/NEJMoa2001017

ZHU, Z. et al. From SARS and MERS to COVID-19: a brief summary and comparison of severe acute respiratory infections caused by three highly pathogenic human coronaviruses. Respiratory research, London, v. 21, n. 1, p. 1-14, 2020.

DOI: 10.1186/s12931-020-01479-w

\section{Authors' contribution}

Yetim and Sönmez contributed the sections of Method and Results; Konca contributed the section of Introduction; Ilgün contributed the section of Final considerations.

Received: 01/22/2021

Resubmitted: $01 / 22 / 2021$

Approved: 07/06/2021 